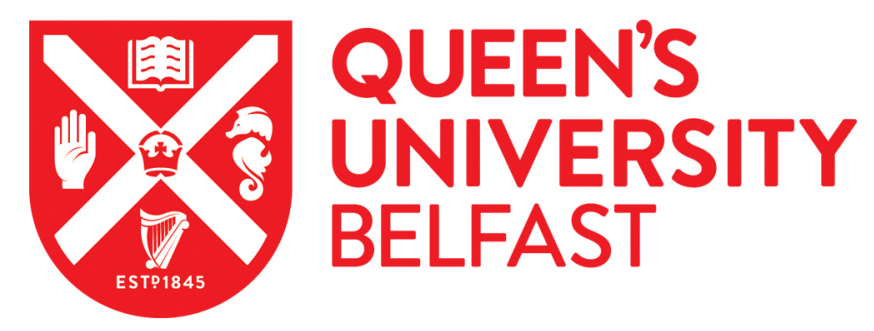

\title{
Effects of business and political ties on product innovation performance: Evidence from China and India
}

Zhang, M., Qi, Y., Wang, Z., Zhao, X., \& Pawar, K. (2019). Effects of business and political ties on product innovation performance: Evidence from China and India. Technovation, 80-81, 30-39.

https://doi.org/10.1016/j.technovation.2018.12.002

\section{Published in:}

Technovation

\section{Document Version:}

Peer reviewed version

Queen's University Belfast - Research Portal:

Link to publication record in Queen's University Belfast Research Portal

\section{Publisher rights}

Copyright 2018 Elsevier Ltd.

This manuscript is distributed under a Creative Commons Attribution-NonCommercial-NoDerivs License

(https://creativecommons.org/licenses/by-nc-nd/4.0/), which permits distribution and reproduction for non-commercial purposes, provided the author and source are cited.

\section{General rights}

Copyright for the publications made accessible via the Queen's University Belfast Research Portal is retained by the author(s) and / or other copyright owners and it is a condition of accessing these publications that users recognise and abide by the legal requirements associated with these rights.

Take down policy

The Research Portal is Queen's institutional repository that provides access to Queen's research output. Every effort has been made to ensure that content in the Research Portal does not infringe any person's rights, or applicable UK laws. If you discover content in the Research Portal that you believe breaches copyright or violates any law, please contact openaccess@qub.ac.uk. 


\title{
Effects of business and political ties on product innovation performance: Evidence from China and India
}

\begin{abstract}
This study investigates the joint effects of business and political ties, cognitive capital, and institutional support on product innovation performance in China and India. The hypotheses are empirically tested using bootstrap and multiple group structural equation modeling methods, and data collected from 300 Chinese and 200 Indian manufacturers. The results reveal that cognitive capital mediates business ties' impacts on product innovation performance in both China and India and that institutional support mediates the effects of business and political ties on product innovation performance only in China. The study also finds that political ties increase institutional support in India and that the effect of cognitive capital on product innovation performance is significantly stronger in India than in China. This study clarifies the mechanisms through which business and political ties enhance product innovation performance and generalizes the results in two emerging markets. The cross-country comparison sheds light on the influences of cultural and institutional environments on such mechanisms and provides insights into how to utilize managers' business and political ties for product innovation in China and India.
\end{abstract}

Keywords: business ties, political ties, cognitive capital, institutional support, product innovation performance, China, India 


\section{Introduction}

China and India have invested heavily in transforming to knowledge economies and Chinese and Indian companies have demonstrated rising levels of innovation performance (Fan, 2011, World Economic Forum, 2014, Zhang et al., 2016). However, although China and India are reforming economies, they haven't become free markets yet and have serious corruption problems (Kozhikode and Li, 2012, World Economic Forum, 2014). Government officials may undermine the rule of law and offer favorable judicial decisions to friends (Cappelli et al., 2010, Parayil and D'Costa, 2009). Hence, it is difficult for Chinese and Indian companies to manage collaboration and protect business interests using contracts and legal means (Wang et al., 2011, Zhou and Poppo, 2010). In addition, both China and India have collectivist cultures (House et al., 2004). Therefore, managers' ties with managers at other companies (i.e. business ties) and government officials (i.e. political ties) have become important ways for companies to acquire resources to support product innovation (Park and Luo, 2001, Power et al., 2010). The objective of this study is to empirically investigate how business and political ties affect product innovation performance in China and India. This study addresses two research questions. First, how do business and political ties, cognitive capital, and institutional support jointly affect product innovation performance in China and India? Second, how do the cultural and institutional environments in China and India influence such effects?

Business and political ties are developed through managers' networking and boundary-spanning activities (Peng and Luo, 2000, Sheng et al., 2011). Researchers have found that they are positively associated with business performance (Li et al., 2008, Luk et al., 2008, Sheng et al., 2011, Wu, 2011, Shu et al., 2012). In particular, business ties can provide a common belief system between managers, facilitating a company to 
develop cognitive capital that helps the company acquire knowledge from and create knowledge together with external partners (Carey et al., 2011, Tsai and Ghoshal, 1998, Roden and Lawson, 2014). Business and political ties can also enhance a company's network and political legitimacy, enabling the company to acquire institutional support that helps the company recognize new market opportunities and obtain governmental resources (Li and Atuahene-Gima, 2001, Hemmert et al., 2016). However, few studies have linked business and political ties with cognitive capital and institutional support and investigated their joint effects on product innovation performance (Yi et al., 2017).

Researchers have argued that a country's cultural and institutional environments influence the effectiveness of business and political ties (Li et al., 2008, Luk et al., 2008, Sheng et al., 2011) and national innovativeness (Fan et al., 2017). China and India have different legal and political systems (Fan, 2011, Parayil and D'Costa, 2009). They also belong to the Confucian and Southern Asian Societal Clusters respectively (House et al., 2004), which exhibit different cultural values and leadership styles (Chokar et al., 2007). However, existing studies have overlooked how the cultural and institutional environments in China and India affect the mechanisms through which business and political ties influence product innovation performance (Kemper et al., 2013, Lawson et al., 2008, Luk et al., 2008, Park and Luo, 2001).

\section{Theoretical background and research hypotheses}

\subsection{Business and political ties}

Business and political ties are the individual level social capital that managers have developed through personal relationships and connections (Peng and Luo, 2000, Sheng et al., 2011). They include exchanges of social obligation by asking and giving favors and hence managers can become insiders of networks (Park and Luo, 2001, Wang et 
al., 2017). Via networking and boundary spanning, managers can broker and mobilize personal connections to benefit from mutual obligations and assurances and gain competitive advantages (Gilsing and Duysters, 2008, Jackson, 2011, Kemper et al., 2013). Business ties refer to a manager's connections with managers at other companies such as suppliers, customers, and competitors (Peng and Luo, 2000). They allow a manager to acquire resources and knowledge from external organizations (Petruzzelli, 2011, Wu, 2011). Political ties refer to a manager's connections with political leaders and officials in industrial bureaus and regulatory and supporting organizations, such as tax bureaus, state banks, and commercial administration bureaus (Peng and Luo, 2000). They enable a manager to obtain scarce governmental resources, such as contract enforcement, bank loans, tax reductions, licenses, land, and subsidies (Guo et al., 2014, Kozhikode and Li, 2012, Li and Zhou, 2010). The extent of social interactions among managers and between managers and government officials reflects the strength of business and political ties respectively (Tsai and Ghoshal, 1998, Villena et al., 2011).

Governments may in command of many scarce and valuable resources and have great influences over companies by devising industry development plans and setting regulatory policies (World Economic Forum, 2014). China and India also lack welldeveloped market-supporting institutions and have collectivist cultures (Luk et al., 2008, Power et al., 2010, Zhou and Poppo, 2010). Hence, business and political ties allow managers cultivate interpersonal relations to acquire information and knowledge and to overcome institutional constraints and resource disadvantages (Li et al., 2008, Kaasa, 2009, Peng and Luo, 2000). There is empirical evidence that business and political ties are positively associated with innovation performance (Kemper et al., 2013, Luk et al., 2008, Shu et al., 2012, Wu, 2011), and that the relationship is influenced by a country's institutional environment ( $\mathrm{Li}$ et al., 2008, Sheng et al., 2011). However, few studies 
have empirically investigated and compared the mechanisms through which business and political ties influence product innovation performance in China and India (Wang et al., 2017).

\subsection{Cognitive capital}

Cognitive capital can be defined as "those resources providing shared representations, interpretations, and systems of meaning among parties" (Nahapiet and Ghoshal, 1998:244). It is the organizational level social capital that facilitates negotiation, provides a harmony of interests, decreases inter-organizational conflict, and promotes collaboration and knowledge exchange and combination (Lawson et al., 2008, Kaasa, 2009). Cognitive capital can be conceptualized as the shared objectives and visions, compatible values and cultures, and common understandings of language and concepts between a company and its external partners (Tsai and Ghoshal, 1998, Villena et al., 2011). Cognitive capital enables a company and its external partners to align goals, develop congruent expectations for cooperation, and hence can suppress opportunistic behavior and facilitate learning and knowledge creation (Roden and Lawson, 2014, Lawson et al., 2008). In particular, the use of common language and concepts helps companies understand one another's cognitive maps and thinking processes, which facilitates interactions and avoids misinterpretation of events (Nahapiet and Ghoshal, 1998). Compatible values and cultures, which refer to the congruent norms of behaviour that govern relationships, motivate companies to make relationship specific investments (Villena et al., 2011). Shared visions and objectives, which refer to the common understanding and approach to the achievement of outcomes, also improve relationship commitments, decreasing the opportunism, risks, and uncertainties involved in cooperation (Roden and Lawson, 2014). Hence, cognitive capital outlines appropriate ways for companies to coordinate their exchange (Carey et 
al., 2011). Empirical evidence has shown that cognitive capital improves business and innovation performance (Carey et al., 2011, Kemper et al., 2013, Villena et al., 2011, Tsai and Ghoshal, 1998).

\subsection{Institutional support}

Institutional support can be defined as "the extent to which administrative institutions (such as government departments) provide support for firms in order to reduce the adverse effects of the inadequate institutional infrastructure" ( $\mathrm{Li}$ and Atuahene-Gima, 2001:1125). The tangible and intangible resources obtained from governments and their agencies, such as beneficial policies and programs and financial and technical support, can affect a company's decisions on innovation (Hemmert et al., 2016, Li and Atuahene-Gima, 2001). As an extralegal formal institution, support from government provides a governance mechanism that controls companies' behaviour, resolves their disputes, and corrects market failures (Hemmert et al., 2016, Shu et al., 2015). Hence, institutional support can be deployed to cope with institutional deficiencies (Sheng et al., 2011). Although researchers have found that institutional support positively affects business performance (Guo et al., 2014, Sheng et al., 2011) and productivity (Guo et al., 2018), there are mixed findings on its influences on product innovation ( $\mathrm{Li}$ and Atuahene-Gima, 2001, Shu et al., 2015, Hong et al., 2016). How regulatory institutions affect innovation performance of emerging market companies is underexplored (Hong et al., 2016, Yi et al., 2017).

\subsection{Research hypotheses}

\subsubsection{Business ties, cognitive capital, and product innovation performance}

Personal ties with suppliers, customers, and competitors allow managers to be involved in networks of mutual acquaintance and recognition that enhance reciprocity and long-term perspectives (Lawson et al., 2008, Luk et al., 2008). Business ties thus 
enable managers to coordinate objectives and achieve a mutual understanding and an awareness of organizational norms through social interactions with other companies (Peng and Luo, 2000). Hence, business ties can lead to collective goals, congruent expectations on the outcomes of cooperation, and common understandings of which activities are best for the collaboration between a company and its partners (Carey et al., 2011). In addition, business ties enable managers and their counterparts in other companies to continuously participate in sense making, which creates congruent objectives and common values and visions (Nahapiet and Ghoshal, 1998). Managers' boundary spanning activities and social interactions also play critical roles in shaping and sharing a common set of language, codes, and practices within a network (Tsai and Ghoshal, 1998). Hence, business ties can benefit a company in developing cognitive capital with other companies.

Cognitive capital can improve the quantity, quality, and speed of information flows between a company and its partners and facilitate them to collaborate on knowledge creation and product innovation (Kemper et al., 2013, Nahapiet and Ghoshal, 1998). In particular, shared values and cultures can motivate external partners to share knowledge and invest in resources for collaborative product innovation (Atuahene-Gima, 2005, Carey et al., 2011, Roden and Lawson, 2014). They also provide congruent interests that suppress opportunistic behavior during collaboration (Villena et al., 2011). The common language, concepts, and understandings shared between a company and its partners promote frequent interactions and avoid miscommunication, and hence improve knowledge exchange and combination (Nahapiet and Ghoshal, 1998). Shared visions and collective goals lead to the same perceptions and anticipations about collaborative innovation and thus decrease the likelihood of conflicts (Zhang et al., 2016). In addition, cognitive capital provides a frame of reference for observing and 
interpreting environments and allows a company to recognize and acquire valuable knowledge from external partners, improving the company's innovation capabilities (Zhang et al., 2016). Hence, cognitive capital mediates business ties' impacts on product innovation performance. Therefore, this study proposes the following hypothesis.

H1. Business ties improve product innovation performance through cognitive capital.

Figure 1 presents the conceptual model and the proposed hypotheses.

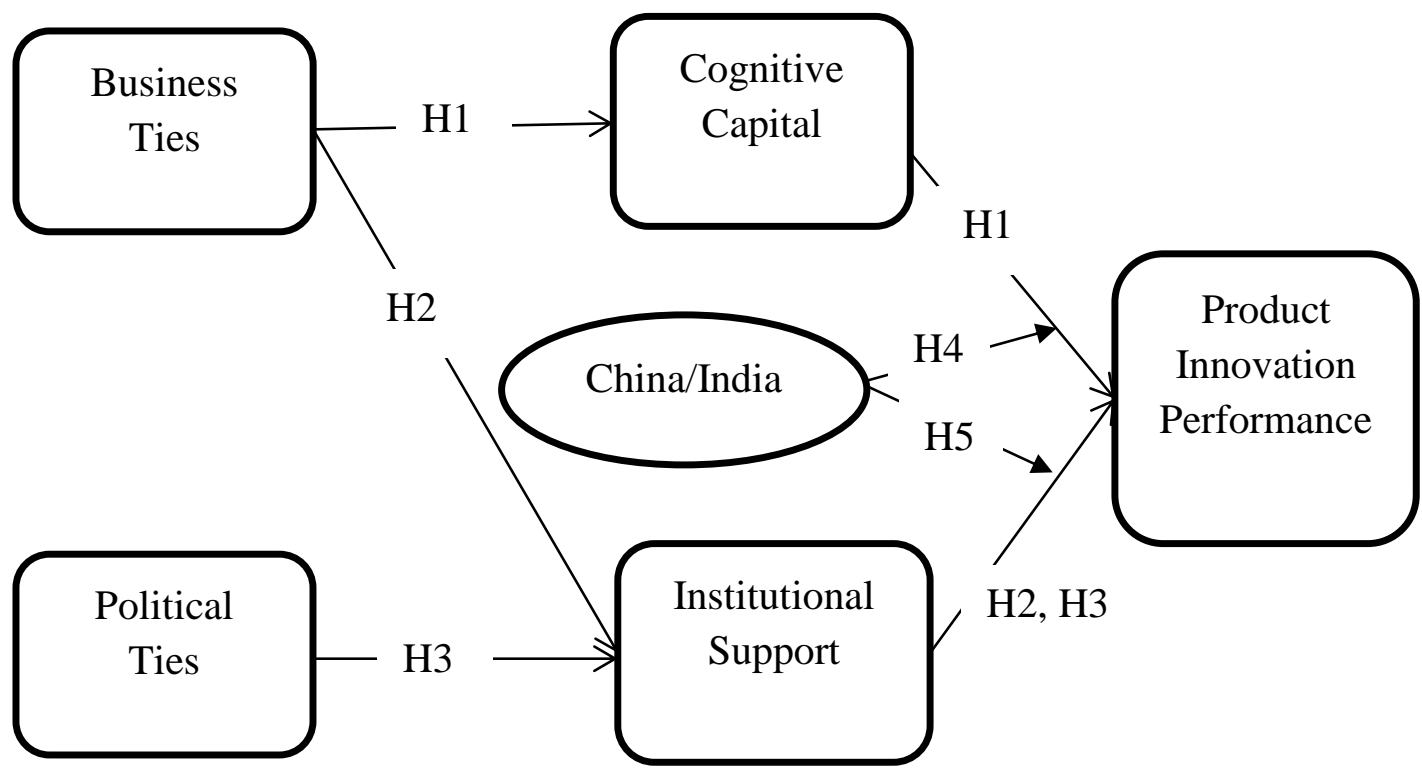

Figure 1. Conceptual framework

\subsubsection{Business and political ties, institutional support, and product innovation} performance

Business ties provide private channels for managers to acquire and disseminate information that may be unavailable in the open market (Shu et al., 2012). Ties with suppliers, customers, and competitors allow companies to learn from and model 
themselves after other successful companies (Peng and Luo, 2000). The network legitimacy helps network members develop common interests and congruent anticipations for collaboration (Shu et al., 2015). Managers are willing to work together to coordinate transactions and solve problems and conflicts through mutually beneficial negotiations and compromises in a business community (Li et al., 2008, Peng and Luo, 2000). Hence, business ties can link network members to form consortiums or associations, which enhance a company's bargaining power with a government. A company can lobby officials to implement beneficial policies and programs and gain technical and financial support from the government through collective efforts of the whole network (Guo et al., 2014, Li and Zhou, 2010).

Political ties can bring a company privileged information about industrial regulations and policies, enabling it to act congruently with the government's rules, norms, and expectations ( $\mathrm{Li}$ and Zhang, 2007). The political legitimacy plays a critical role in a company's acquisition of favorable government treatment (Sheng et al., 2011) and resources such as technical and financial support from regulatory agencies and bureaus (Guo et al., 2014). Ties with government officials and political leaders also allow a company to influence local authorities to set regulations or policies that protect it from unfair or unethical competitive practices or opportunistic behavior even when a rule of law is lacking (Cai et al., 2010, Guo et al., 2014). Hence, political ties not only reduce institutional uncertainties by ensuring fewer bureaucratic delays and better legal protections, but also enable a company to influence the design and implementation of governmental policies and programs to gain desired results (Li and Zhang, 2007, Li and Zhou, 2010).

Institutional support can exert considerable influences on a company' innovation decisions by providing financial and technical resources and favorable industry 
development plans and regulatory policies (Guo et al., 2014, Hemmert et al., 2016). In particular, favorable policies and regulations can protect a company's intellectual property rights and substitute weak legal systems to eliminate dysfunctional competition and enforce contracts in a way that allows the company to benefit from product innovations (Zhou and Poppo, 2010). Incentive programs can also motivate a company to invest in product innovation (Fan, 2011, Shu et al., 2015). In addition, the technical information and support provided by a government helps a company learn technological inventions or breakthroughs on product designs from advanced competitors, improving the company's product innovation performance ( $\mathrm{Li}$ and Atuahene-Gima, 2001, Shu et al., 2015). The financial support can be deployed to improve a company's innovation activities, increasing the number of new products developed (Atuahene-Gima, 2005, Shu et al., 2015). Government support for technology and equipment imports also enhances the speed and frequency with which new products are introduced (Guo et al., 2014). Hence, institutional support mediates business and political ties' impacts on product innovation performance. Therefore, this study proposes the following hypotheses.

H2. Business ties improve product innovation performance through institutional support.

H3. Political ties improve product innovation performance through institutional support.

2.4.3 The impacts of cultural and institutional environments: A comparison between

\section{China and India}

Compared with Chinese culture, Indian culture is characterized by lower humane orientation (i.e. the degree to which a collective encourages and rewards individuals for being fair, altruistic, generous, caring, and kind to others) and uncertainty avoidance 
(i.e. the extent to which an organization relies on social norms, rules, and procedures to alleviate unpredictability of future events), whereas higher future orientation (i.e. the extent to which individuals engage in future-oriented behavior such as delaying gratification and planning and investing in the future) in both cultural practices (as is) and values (should be) (House et al., 2004, Chokar et al., 2007). Hence, cognitive capital plays a more important role in improving product innovation performance in India. First, Indian managers are relatively less humane oriented, and hence tend to manage collaboration based on their assessments of partners' abilities to meet obligation and skills in performing specific tasks (Chokar et al., 2007). In contrast, Chinese managers value altruism and kindness and encourage and reward individuals for being fair, friendly, generous, and caring (Chokar et al., 2007). They rely on their perceptions of partners' intentions, goodwill, and benevolence to manage collaborations (Wang et al., 2011). Common language and concepts build a foundation for a company to exchange information with external partners and to evaluate their capabilities and competence, and hence play more critical roles in acquiring resources for product innovation in India. Second, higher future orientation indicates that Indian managers are more likely to engage in strategic planning and invest in long-term relationships (House et al., 2004). Shared objectives and visions lead to common interests and strategic congruence between a company and its partners, which enable Indian companies to align long-term plans, decisions, and investments for product innovation (Tsai and Ghoshal, 1998), and thus are more important in motivating a company to invest in relationship specific assets for acquiring and applying knowledge from partners in India. Third, lower uncertainty avoidance indicates that Indian managers often use informality in interaction with others and rely on informal norms, instead of established social rules and bureaucratic practices, to alleviate 
unpredictability and risks (House et al., 2004). Indian managers also accept and feel comfortable in unstructured situations or changeable environments (Chokar et al., 2007). Common values and cultures provide a referent guideline and framework for a company and its partners to develop informal and unstructured procedures and regulations to solve conflict and manage interactions, and hence cognitive capital is more important in facilitating collaborative product innovation in India (Kemper et al., 2013, Villena et al., 2011). Therefore, this study proposes the following hypothesis.

H4. The effect of cognitive capital on product innovation performance is stronger in India than in China.

China and India have different institutional environments, which influence the effect of institutional support on product innovation performance. Specifically, China's Communist Party has ultimate authority throughout the economic system (Parayil and D'Costa, 2009). The Chinese government has considerable power to create policies, make public spending decisions, allocate resources, and approve projects (Cai et al., 2010, Zhou and Poppo, 2010). In addition, Chinese government officials actively participate in business operations and play the roles of advocate and adviser to companies because they are appraised and promoted according to the success of the business entities within their jurisdictions (Cai et al., 2010, Shu et al., 2015). To become successful in their political careers, government officials tend to devise special programs and provide support to promote local companies' innovation activities (Guo et al., 2014, Wang et al., 2011). In contrast, India is a democratic and pluralist society with a multi-party system (Kozhikode and Li, 2012). Although Indian National Congress and Bharatiya Janata Party are the main national parties, there are many regional parties that rule local governments. Compared with Chinese officials, Indian officials are less proactive and powerful in managing the economy (World Economic 
Forum, 2014). Political pluralism may decrease the influence of institutional support on business operations, as the political parties controlling the different levels of government may exhibit competing policy preferences (Kozhikode and Li, 2012). Hence, institutional support plays a more important role in improving product innovation performance in China. Therefore, this study proposes the following hypothesis.

H5. The effect of institutional support on product innovation performance is stronger in China than in India.

\section{Research method}

\subsection{Questionnaire design}

A survey instrument was designed to measure the business and political ties of a company's senior managers along with the company's cognitive capital, institutional support, and product innovation performance. The questionnaire also included the demographic profile of the company and was designed in English. A multiple-item, 7point Likert-type scale was employed for all constructs. The research team organized a panel of academics to review the English version of the questionnaire and translated it into Chinese. The Chinese version was then translated back into English and checked against the original English version to verify its reliability. The English version was used in India and the Chinese version was used in China to collect data. The scales, which consist of 18 measurement items, are listed in the Appendix I.

The measures for political and business ties were adapted from Peng and Luo (2000) and Li et al. (2008). Business ties were gauged by three items reflecting the extent to which senior managers build personal connections with senior managers at customers, suppliers, and competitors. Political ties were measured by three items indicating the 
extent to which senior managers utilize their personal ties, networks, and connections with political leaders and officials from different governmental institutions. Cognitive capital was measured using four items that were adapted from Tsai and Ghoshal (1998) and Villena et al. (2011). They captured the shared objectives, visions, values, and cultures, and common codes and language between a company and major partners. The four items gauging institutional support were adopted from Li and Atuahene-Gima (2001). They captured the favourable policies and programs, technical and financial resources, and permission for business actions a company obtained from government and its agencies. Product innovation performance was measured by four items related to the number of new products developed and the speed and frequency of new product introduction (Atuahene-Gima, 2005, Chandy and Tellis, 1998).

Research and development (R\&D) investment was included as a control variable in the analysis as companies who have invested more in $R \& D$ tend to have better product innovation performance. It was measured by the percentage of annual sales invested in R\&D. Large companies may have higher capabilities and more resources for product innovation. Company size, which was measured by the number of employees, was also controlled. Moreover, this study controlled for training investment as training can upgrade employees' skills which may improve product innovation performance. This was measured by the percentage of annual sales spent on training.

\subsection{Data collection}

The research team interviewed 15 manufacturing companies in China to pilot test the questionnaire. It was then decided to use one key informant per company who had personal connections with managers at other companies and government officials and was knowledgeable about the company's product innovation performance. These key 
informants included general managers, directors, and senior R\&D, operations/manufacturing, and supply chain managers.

In China, manufacturing companies were selected from three special economic zones (i.e. Pearl River Delta, Yangtze River Delta, and Bohai Economic Rim). The research team randomly selected 2379 manufacturing companies from the target industries (Table 1) in the three regions using the directory provided by the National Bureau of Statistics of the People's Republic of China. A professional market research firm was hired to conduct the data collection. The firm contacted the target companies by telephone to identify the potential respondents and solicit their participation in the survey. Of the selected sample, 2061 could not be contacted due to missing or incorrect contact information or did not wish to participate in the survey. The market research firm sent representatives to visit the respondents of the remaining 318 companies on site. Finally, 300 completed questionnaires were returned for a response rate of $12.6 \%$ $(300 / 2379)$.

In India, manufacturing companies were randomly selected from the important industrial cities, including Delhi, Mumbai, Bangalore, Chennai, Kolkata, Chandigarh, and Ahmadabad, and from the same industries as those in China. The companies were selected from the business directory provided by IndiaMart, the most comprehensive business directory in India. A professional market research firm was also hired for data collection. Using a similar approach, the firm contacted target companies by telephone to identify appropriate respondents, resulting in a sample of 550 companies who agreed to participate in the survey. The firm sent representatives to collect data via face-to-face interviews with the appropriate respondents and ultimately collected 200 valid questionnaires for a response rate of $36.4 \%$ (200/550). The demographic statistics of the sample manufacturing companies are shown in Table 1. 
Table 1. Company profiles

\begin{tabular}{|c|c|c|}
\hline & China & India \\
\hline \multicolumn{3}{|l|}{ Annual sales (USD) } \\
\hline Less than 50 million & $62.3 *$ & 78.0 \\
\hline 50 to 100 million & 17.0 & 10.5 \\
\hline 100 to 250 million & 12.0 & 4.5 \\
\hline More than 250 million & 8.7 & 7.0 \\
\hline \multicolumn{3}{|l|}{ Industry } \\
\hline Biology \& pharmaceuticals & 6.0 & 16.0 \\
\hline Computer \& telecommunication equipment & 11.3 & 6.5 \\
\hline Chemicals & 17.0 & 9.5 \\
\hline Medical equipment & 9.3 & 3.5 \\
\hline Electronics \& electrical equipment & 18.0 & 21.0 \\
\hline Industrial machinery & 16.3 & 27.5 \\
\hline Transportation equipment & 11.7 & 6.0 \\
\hline New materials & 10.3 & 4.0 \\
\hline \multicolumn{3}{|l|}{ Years of operation } \\
\hline Less than 10 years & 26.7 & 25.0 \\
\hline 11 to 20 years & 46.6 & 44.0 \\
\hline 21 to 30 years & 11.0 & 19.5 \\
\hline More than 30 years & 16.7 & 11.5 \\
\hline \multicolumn{3}{|l|}{ Number of employees } \\
\hline Less than 200 & 22.3 & 64.8 \\
\hline 201 to 500 & 41.7 & 16.6 \\
\hline 501 to 1000 & 17.3 & 9.1 \\
\hline More than 1000 & 18.7 & 9.5 \\
\hline \multicolumn{3}{|l|}{ R\&D investment (\% of annual sales) } \\
\hline Less than $0.5 \%$ & 12.3 & 24.0 \\
\hline $0.51 \%$ to $1.0 \%$ & 8.7 & 38.5 \\
\hline $1.1 \%$ to $2.0 \%$ & 15.0 & 13.5 \\
\hline 2.1 to $4.0 \%$ & 48.0 & 8.0 \\
\hline More than $4.0 \%$ & 16.0 & 16.0 \\
\hline \multicolumn{3}{|l|}{ Training budget (\% of annual sales) } \\
\hline Less than $1.0 \%$ & 68.3 & 27.0 \\
\hline $1.1 \%$ to $2.0 \%$ & 18.0 & 40.5 \\
\hline $2.1 \%$ to $4.0 \%$ & 13.7 & 19.5 \\
\hline More than $4.0 \%$ & 0.0 & 13.0 \\
\hline
\end{tabular}

Note: * percentage of companies

To test common method bias, a confirmatory factor analysis (CFA) model was applied to the Harman's single factor model (Podsakoff et al., 2003). The fit indices in the $\quad$ Chinese $\quad$ are $\quad \chi^{2}(135)=1248.80, \chi^{2} / \mathrm{df}=9.25$, Comparative Fit Index $(\mathrm{CFI})=0.50$, Tucker - Lewis Index $(\mathrm{TLI})=0.44$, Root Mean Square Error of Approximation $($ RMSEA) $=0.17$. The fit indices in the 
Indian sample are $\chi^{2}(135)=1216.86, \quad \chi^{2} / \mathrm{df}=9.01, \mathrm{CFI}=0.44, \quad$ TLI $=$ 0.36 , RMSEA $=0.20$. These results suggest little common method bias. In addition, a measurement model including only traits and one including both traits and a common method factor were tested in the two samples. The model fit indices of the method factor models are marginally improved. Meanwhile, the path coefficients of the trait factors and their significance are similar between the two models in both Chinese and Indian samples. This suggests that they are robust, though a method factor was included in the method factor models. Hence, common method bias is not a serious concern (Podsakoff et al., 2003).

\subsection{Psychometric test}

Cronbach's alpha and composite reliability were employed for assessing construct reliability. The Cronbach's alpha values range from 0.66 to 0.92 and the composite reliabilities range from 0.81 to 0.95 (Appendix I), all of which are above the recommended threshold value of 0.70 except for one Cronbach's alpha value that is slightly lower. However, the composite reliability for the same construct is higher than 0.70, suggesting that all constructs are reliable in both Chinese and Indian samples.

This study used average variance extracted (AVE) to assess the convergent validity. The AVE values range from 0.56 to 0.82 , which are above the recommended threshold value of 0.50 (Appendix I) (Fornell and Larcker, 1981). The study also built a CFA model in which each item was linked to its corresponding construct and the covariance among the constructs was freely estimated. The model fit indices in the Chinese sample are $\chi^{2}(125)=238.36, \chi^{2} / \mathrm{df}=1.91, \mathrm{CFI}=0.95, \mathrm{TLI}=0.94, \mathrm{RMSEA}=0.055$. The model fit indices in the Indian sample are $\chi^{2}(125)=258.36, \chi^{2} / \mathrm{df}=2.07, \mathrm{CFI}=$ 0.93 , TLI $=0.92$, RMSEA $=0.073$. These results are better than the threshold values recommended by $\mathrm{Hu}$ and Bentler (1999). All the factor loadings are greater than 0.60 
(ranging from 0.666 to 0.928 ) (Appendix I) and all $t$ values are greater than 2.0. The results indicate that convergent validity is ensured in both Chinese and Indian samples.

Discriminant validity was assessed by comparing the square roots of the AVE of each construct with the correlations between the focal construct and each other construct. A square root higher than the correlation with the other constructs suggests discriminant validity (Fornell and Larcker, 1981). Table 2 shows the variance, minimum, maximum, mean, and standard deviation of the constructs and their correlations. A comparison of all of the correlations and square roots of the AVEs on the diagonal indicates adequate discriminant validity for all constructs in both Chinese and Indian samples (Fornell and Larcker, 1981). Discriminant validity was also assessed by building constrained CFA models for every possible pair of latent constructs, in which the correlations between the paired constructs were fixed at 1.0. They were compared with the original unconstrained model, in which the correlations between constructs were freely estimated. A significant difference in the chi-square statistics between the constrained and unconstrained models indicates high discriminant validity (Fornell and Larcker, 1981). This method was applied to both Chinese and Indian samples and all differences are significant at the 0.001 level, indicating that discriminant validity is ensured.

Table 2. Correlations and descriptive statistics

\begin{tabular}{|c|c|c|c|c|c|c|}
\hline & & PT & BT & $\mathrm{CC}$ & IS & PIP \\
\hline \multirow[t]{10}{*}{ China } & Political ties (PT) & $\mathbf{0 . 8 8}$ & & & & \\
\hline & Business ties (BT) & $0.42^{* *}$ & 0.77 & & & \\
\hline & Cognitive capital (CC) & $0.19^{* *}$ & $0.34^{* *}$ & 0.75 & & \\
\hline & Institutional support (IS) & $0.45^{* *}$ & $0.33^{* *}$ & $0.30^{* *}$ & 0.84 & \\
\hline & $\begin{array}{l}\text { Product innovation } \\
\text { performance (PIP) }\end{array}$ & $0.27^{* *}$ & $0.20^{* *}$ & $0.27^{* *}$ & $0.35^{* *}$ & 0.85 \\
\hline & Mean & 5.09 & 5.00 & 5.24 & 4.53 & 4.65 \\
\hline & Standard deviation & 1.11 & 0.93 & 0.88 & 1.14 & 1.10 \\
\hline & Variance & 1.24 & 0.87 & 0.77 & 1.31 & 1.21 \\
\hline & Minimum & 1.00 & 2.00 & 2.25 & 1.00 & 1.50 \\
\hline & Maximum & 7.00 & 7.00 & 7.00 & 7.00 & 7.00 \\
\hline
\end{tabular}




\begin{tabular}{|c|c|c|c|c|c|c|}
\hline \multirow{10}{*}{ India } & Political ties & 0.85 & & & & \\
\hline & Business ties & $0.44^{* *}$ & 0.85 & & & \\
\hline & Cognitive capital & $0.40^{* *}$ & $0.47^{* *}$ & 0.80 & & \\
\hline & Institutional support & $0.30^{* *}$ & 0.08 & $0.20^{* *}$ & 0.91 & \\
\hline & $\begin{array}{l}\text { Product innovation } \\
\text { performance }\end{array}$ & $0.31^{* *}$ & $0.63^{* *}$ & $0.40^{* *}$ & 0.01 & 0.82 \\
\hline & Mean & 5.24 & 5.55 & 5.50 & 4.83 & 5.45 \\
\hline & Standard deviation & 1.11 & 0.92 & 0.89 & 1.48 & 0.80 \\
\hline & Variance & 1.23 & 0.85 & 0.79 & 2.20 & 0.63 \\
\hline & Minimum & 1.00 & 2.00 & 1.00 & 1.00 & 2.25 \\
\hline & Maximum & 7.00 & 7.00 & 7.00 & 7.00 & 7.00 \\
\hline
\end{tabular}

Note: Square root of average variance extracted (AVE) is shown on the diagonal of each matrix in bold and off-diagonal entries are the correlations between constructs; ** $\mathrm{p}<0.01$

\subsection{Measurement equivalence}

To ensure cross-country comparability, the empirical assessment of measurement equivalence of the constructs between the two countries was conducted. Measurement equivalence refers to the capability of a scale to yield accurate measurement of contextual issues across different settings (Rungtusanatham et al., 2008). It guarantees that cross-country differences are not caused by the differences in measurement scales.

This study assessed the measurement equivalence across the Chinese and Indian samples using the multiple group CFA method recommended by Rungtusanatham et al. (2008). First, a stacked model was built to assess the configural equivalence, which refers to the extent to which the data collected from China and India share the same factor structure. The configural model fits well across the two samples $\left(\chi^{2}(250)=\right.$ 496.82, $\left.\chi^{2} / \mathrm{df}=1.99, \mathrm{CFI}=0.94, \mathrm{TLI}=0.93, \mathrm{RMSEA}=0.045\right)$, and all of the factor loadings and variances are statistically significant. These results establish configural equivalence across the two samples (Rungtusanatham et al., 2008). Second, metric equivalence was assessed by a nested CFA model, which determines the extent to which the individual factor loadings are identical across the two samples. In this model, the factor loadings were constrained to be equal across the two samples and other parameters were freely estimated. The significant change $\left(\Delta \chi^{2}(13)=29.70\right)$ 
between the unconstrained and constrained models shows that the metric invariance is not accepted, which suggests a further assessment of whether some of the measures satisfy the metric invariance (Rungtusanatham et al., 2008). Third, this study followed the procedure suggested by Rungtusanatham et al. (2008) to revise the constrained model by releasing the factor loadings of the constructs one by one. This study then compared the revised and constrained models to identify which factor loadings are variant between the samples. Only one factor loading differs significantly between the two samples (Table 3). Next, a partial metric invariant model was constructed in which the preceding factor loading is unconstrained and the other factor loadings are fully constrained to be equal between the groups. The insignificant change $\left(\Delta \chi^{2}(12)=19.07\right)$ indicates that the partial metric invariance is accepted. As suggested by Rungtusanatham et al. (2008), the partial metric invariant model is enough for further comparative analyses across different national samples.

Table 3. Results of comparisons of the revised and constrained models

\begin{tabular}{|l|l|l|l|}
\hline Construct & Item & $\Delta \chi^{2}$ & p-value \\
\hline \multirow{3}{*}{ Political ties } & PT2 $^{\text {a }}$ & 0.84 & 0.36 \\
\cline { 2 - 4 } & PT3 & 2.41 & 0.12 \\
\hline \multirow{3}{*}{ Business ties } & BT2 & 7.71 & $0.01^{*}$ \\
\cline { 2 - 4 } & BT3 & 0.06 & 0.81 \\
\hline \multirow{5}{*}{ Cognitive capital } & CC2 & 0.00 & 0.97 \\
\cline { 2 - 4 } & CC3 & 2.06 & 0.15 \\
\cline { 2 - 4 } & CC4 & 0.16 & 0.69 \\
\hline Institutional support & IS2 & 0.38 & 0.54 \\
\cline { 2 - 4 } & IS3 & 0.92 & 0.34 \\
\cline { 2 - 4 } & IS4 & 0.10 & 0.76 \\
\hline Product Innovation performance & PIP2 & 0.13 & 0.72 \\
\cline { 2 - 4 } & PIP3 & 0.29 & 0.59 \\
\cline { 2 - 4 } & PIP4 & 3.80 & 0.06 \\
\hline
\end{tabular}

Note: $* \mathrm{p}<0.05$; ${ }^{\text {a }}$ Please refer to the Appendix I for the full description of the items; the factor loading of the first item of each construct is standardized.

\section{Analysis and results}

This study conducts the variance inflation factor and Durbin-Wu-Hausman tests to assess the multicollinearity and endogeneity (Greene, 2012). The results show that 
multicollinearity and endogeneity are not serious concerns in this study (Appendix II). Structural equation modeling (SEM) with the maximum likelihood estimation method and the AMOS 21.0 program are used to test the research model (e.g. Lawson et al., 2008, Shu et al., 2012, Wang et al., 2016). The proposed model for each sample (i.e. China and India) is stacked and the path loadings for measurement items in the two samples are constrained to be equal except for one item identified in the previous procedure. The model fit indices are $\chi^{2}(361)=755.50, \chi^{2} / \mathrm{df}=2.09, \mathrm{CFI}=0.91$, TLI $=0.90$, RMSEA $=0.047$, which are acceptable $(\mathrm{Hu}$ and Bentler, 1999). The standardized path coefficients are reported in Figure 2. In the Chinese sample, business ties significantly influence cognitive capital $(b=0.50, \mathrm{p}<0.01)$ and institutional support $(b=0.21, \mathrm{p}<0.05)$. Political ties significantly increase institutional support $(b=0.44$, $\mathrm{p}<0.01)$. Both cognitive capital $(b=0.22, \mathrm{p}<0.05)$ and institutional support $(b=0.32$, $\mathrm{p}<0.01)$ enhance product innovation performance. In the Indian sample, business ties positively influence cognitive capital $(b=0.69, \mathrm{p}<0.01)$, which significantly increases product innovation performance $(b=0.58, \mathrm{p}<0.01)$. Political ties significantly increase institutional support $(b=0.42, \mathrm{p}<0.01)$. However, the effect of business ties on institutional support and that of institutional support on product innovation performance are not significant. In addition, the results reveal that the effects of company size and training investment on product innovation performance are not significant. R\&D investment significantly affects product innovation performance in the Indian sample $(b=0.18, \mathrm{p}<0.05)$, whereas its effect in the Chinese sample is not significant. 


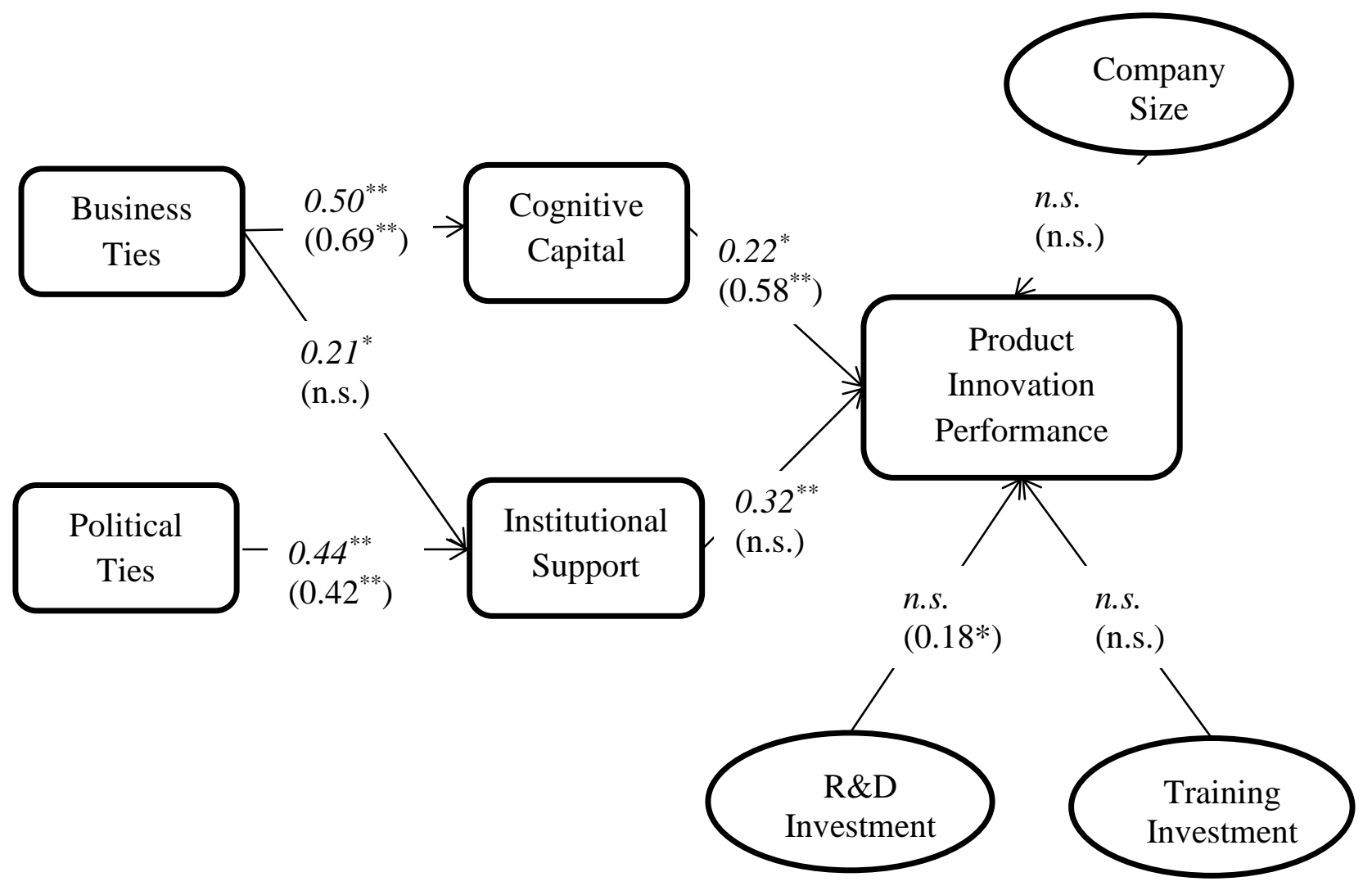

Note: $* \mathrm{p}<0.05 ; * * \mathrm{p}<0.01$; n.s. not significant. The results of the Chinese sample are shown in italic font and those of the Indian sample are shown in parentheses.

Figure 2. Results of the structural model

The hypotheses are assessed by examining the indirect effects of business and political ties on product innovation performance through cognitive capital and institutional support, with their significance levels determined by the bias-corrected bootstrap method (Preacher and Hayes, 2008) using a 95\% confidence level and employing 5000 samples. In the Chinese sample, the results show that the biascorrected $95 \%$ confidence interval for the indirect effect of business ties on product innovation performance through cognitive capital is $(0.011,0.112)$ and through institutional support is $(0.049,0.143)$. The indirect effect of political ties on product innovation performance through institutional support is $(0.068,0.171)$. In the Indian sample, the results show that the bias-corrected $95 \%$ confidence interval for the indirect 
effect of business ties on product innovation performance through cognitive capital is $(0.001,0.153)$ whereas through institutional support is $(-0.047,0.013)$. The indirect effect of political ties on product innovation performance through institutional support is $(-0.072,0.050)$. Thus, cognitive capital mediates business ties' effects on product innovation performance in both Chinese and Indian samples. Institutional support mediates business and political ties' effects on product innovation performance only in the Chinese sample. Therefore, $\mathrm{H} 1$ is supported, whereas $\mathrm{H} 2$ and $\mathrm{H} 3$ are partially supported.

A multiple group SEM analysis is further conducted to compare the relationships among business and political ties, cognitive capital, institutional support, and product innovation performance in China and India. Table 4 summarizes the results of the crosscountry comparisons for the path coefficients.

Table 4. Multiple group analysis

\begin{tabular}{|l|c|c|c|}
\hline \multicolumn{1}{|c|}{ Equal Paths } & $\Delta C F I$ & $\Delta T L I$ & $\Delta \chi^{2}$ \\
\hline Business ties $\rightarrow$ Cognitive capital & 0.000 & 0.000 & 0.83 \\
\hline Business ties $\rightarrow$ Institutional support & -0.001 & -0.001 & $6.24^{*}$ \\
\hline Political ties $\rightarrow$ Institutional support & 0.000 & 0.000 & 0.37 \\
\hline Cognitive capital $\rightarrow$ Product innovation performance & -0.001 & -0.000 & $2.74^{+}$ \\
\hline Institutional support $\rightarrow$ Product innovation performance & -0.004 & -0.004 & $19.43^{* *}$ \\
\hline
\end{tabular}

Note: ${ }^{+} \mathrm{p}<0.1 ;{ }^{*} \mathrm{p}<0.05 ; * * \mathrm{p}<0.01$

The path coefficients from business ties to institutional support and from cognitive capital and institutional support to product innovation performance differ significantly between the Chinese and Indian samples. The path coefficient from cognitive capital to product innovation performance is significantly higher in the Indian sample than in the Chinese sample $\left(\Delta \chi^{2}=2.74\right)$. Hence, H4 is supported. The path coefficient from institutional support to product innovation performance is not significant in the Indian sample but significant and positive in the Chinese sample, and the difference is significant $\left(\Delta \chi^{2}=19.43\right)$. These results indicate that institutional support only enhances 
product innovation performance in the Chinese sample. Hence, H5 is supported. In addition, the path coefficient from business ties to institutional support is not significant in the Indian sample but significant and positive in the Chinese sample, and the difference is significant $\left(\Delta \chi^{2}=6.24\right)$. Hence, business ties increase institutional support only in the Chinese sample. Furthermore, the path coefficients from business ties to cognitive capital and from political ties to institutional support are significant and positive and not significantly different between the Chinese and Indian samples.

\section{Discussion}

\subsection{Implications to theory}

This study contributes to literature in four ways. First, the results show that cognitive capital is the underlying mechanism that connects business ties and product innovation performance. The finding is consistent with existing results on the effects of business ties (Li et al., 2008, Peng and Luo, 2000) and cognitive capital (Lawson et al., 2008, Tsai and Ghoshal, 1998, Villena et al., 2011). The result links managers' personal ties with organizational cognitive capital, enhancing current knowledge on how to develop cognitive capital in emerging markets (Nahapiet and Ghoshal, 1998, Luk et al., 2008). The findings also indicate that business ties and cognitive capital are interrelated and to fully reap the benefits of business ties on product innovation, companies should invest in building cognitive capital with partners at the same time. This improves current understandings on the effects of business ties and cognitive capital (Sheng et al., 2011, Wang et al., 2017).

Second, the results show that the impact of cognitive capital on product innovation is stronger in India, providing empirical evidence that the effectiveness of cognitive capital is contingent on cultural environments. Guanxi (i.e. an intricate and pervasive 
relational network that contains implicit mutual obligations, assurances, and understandings) is a special feature of the Chinese culture (Park and Luo, 2001, Chokar et al., 2007). Chinese managers are bounded by social obligations, which include reciprocal exchange of personal favors and maintaining harmonious relationships among people (Chokar et al., 2007). Hence, Chinese companies rely more on emotional attachment, goodwill, and benevolence when selecting partners and managing collaborative innovation (Wang et al., 2011, Yeung et al., 2009). Cognitive capital is related to norms of behavior and common understandings about tasks and it enables a company to assess partners' ability to perform according to agreements and fulfill promises, and hence it plays a more important role for Indian companies to acquire knowledge from external partners to improve product innovation performance. Therefore, the result enhances the existing knowledge on the influences of culture on the effects of social capital (Yeung et al., 2009, Power et al., 2010) and on innovation (Fan et al., 2017).

Third, this study provides empirical evidence that institutional support mediates business and political ties' effects on product innovation performance only in China. The finding is consistent with existing empirical evidence on the performance outcomes of business and political ties (Sheng et al., 2011, Kemper et al., 2013, Shu et al., 2012) and institutional support (Cai et al., 2010, Guo et al., 2014). The results reveal that business and political ties play different roles in acquiring institutional support in China and India. This extends previous studies by providing support for the contingency view of business and political ties (Li et al., 2008, Sheng et al., 2011), and hence deepens current understandings of the distinctive effects of business and political ties and how to obtain institutional support in different emerging markets (Luk et al., 2008, Wu, 2011, Guo et al., 2018). The findings also enhance current knowledge on the roles played by 
institutions in providing potentials for companies to develop innovations in different emerging markets (Hong et al., 2016, Yi et al., 2017).

Fourth, although institutional support is generally believed to be beneficial for companies in emerging markets (Cai et al., 2010, Guo et al., 2014), the findings show that institutional support enhances product innovation performance in China but not in India. The results indicate that the effectiveness of support from government is influenced by the institutional environment of a country, providing a possible explanation for the inconclusive findings on the effects of institutional support ( $\mathrm{Li}$ and Atuahene-Gima, 2001, Shu et al., 2015) and improving existing knowledge on when governments may solve market failures (Guo et al., 2018). Surprisingly little empirical evidence of the effects of business and political ties in India has been produced. This study fills this void by generalizing the findings in China and India. The cross-country comparison provides fresh insights into the influences of business and political connections on product innovation (Wang et al., 2017) and the impacts of cultural and institutional environments in emerging markets (Fan et al., 2017, Guo et al., 2018).

\subsection{Implications to practice}

This study provides guidelines for companies on how to take advantages of managers' business and political ties for product innovation in China and India. The findings show that managers' business ties build a foundation for cognitive capital between companies which enhances product innovation performance. Hence, Chinese and Indian companies should promote managers' boundary spanning activities and organize social events, such as workshops, seminars, and exhibitions, to help managers develop personal connections with colleagues at suppliers, customers, and competitors. Chinese and Indian companies should also invest in building cognitive capital with partners simultaneously. For example, Chinese and Indian companies could develop 
formal and informal organizational procedures to establish congruent objectives, compatible values, and common language and codes with partners. They could select partners based on cognitive capital and collaborate with the partners that have common visions and cultures for new product development. Moreover, managers should be aware that the effectiveness of cognitive capital is influenced by the cultural environment of a country. Cognitive capital plays a more important role in product innovation in Indian culture than in Chinese culture.

Chinese managers should also invest in building personal ties with political leaders in both central and local governments, and with officials in various industrial bureaus and regulatory and supporting organizations, such as tax bureaus, state banks, and commercial administration bureaus. Chinese managers could use business and political ties to obtain institutional support. Moreover, Chinese managers should adjust new product development strategies according to governmental policies and programs and seek technical and financial resources from governments to support product innovation. However, managers should be aware that the effectiveness of institutional support is influenced by the institutional environment of a country. Indian managers should be warned that although political ties can bring institutional support, the support may not have positive effects on product innovation. Therefore, Indian companies should focus on developing business ties and cognitive capital for product innovation. Chinese companies should take a balanced perspective by relying on both business and political ties, and actively develop cognitive capital and seek institutional support at the same time for new product development.

\subsection{Implications to policy}

The findings reveal that managers' personal relationships with political leaders and officials in different governmental institutions play crucial roles for companies to obtain 
support from governments. Therefore, this study suggests policy makers in China and India establish formal market institutional systems to reduce the impacts of political ties on governmental resource allocation. For example, efficient legal frameworks should be developed for settling disputes and challenging the legality of government actions and regulations. Policies should be devised to prevent Chinese and Indian government officials from showing favoritism to well-connected individuals when formulating regulations and making decisions, and to punish government officials who divert public funds to companies or influence judiciaries due to corruption. In addition, Chinese government should reconsider the criteria for officials' promotion. A balanced approach should be adopted to ensure that officials are not evaluated only according to the economic performance of local businesses' performance. In India, each state has its own government that formulates local policies, and hence government power is fragmented as both national and regional governments can exert formal authority over public decisions related to the allocation and distribution of resources. Hence, Indian government plays a less active and direct role in governing economic activities and supporting product innovation. This study thus suggests Indian policy makers develop procedures to coordinate the regulations and rules devised by national and reginal governments and to promote the cooperation between different political parties to create consistent and effective policies to support innovation.

\section{Conclusions}

This study clarifies the mechanisms through which business and political ties improve product innovation performance. Based on a sample of 300 Chinese and 200 Indian manufacturers, this study finds that the effect of business ties on product innovation performance is transmitted by cognitive capital in both China and India and 
that cognitive capital plays a less important role in improving product innovation performance in China. The results also show that institutional support mediates the effects of business and political ties on product innovation performance in China. Both Chinese and Indian companies rely on political ties to obtain institutional support, whereas business ties cannot bring companies institutional support in India. In addition, institutional support enhances product innovation performance in China but not in India.

Although this study makes significant theoretical and practical contributions, it has limitations that open avenues for future research. First, this study focuses on two emerging markets and the results may be influenced by confounding factors. Developed countries have different business, institutional, and cultural environments compared with China and India. It would be worthwhile to investigate the effects of business and political ties on product innovation performance in developed countries and compare the results with this study, which can decrease the potential for confounding. Second, this study assumes that companies in a country have similar cultural values. Future studies could explicitly measure the cultural values (e.g. humane orientation, uncertainty avoidance, and future orientation) within individual companies and investigate their impacts on the effects of managerial ties on innovation. Third, this study uses subjective measures to gauge product innovation performance. Future studies could measure product innovation performance using objective measures to validate the findings. Fourth, some factors that influence both product innovation performance and business and political ties might be omitted in the model, and hence endogeneity is a limitation of this study.

\section{References}


Atuahene-Gima, K. (2005), "Resolving the capability-rigidity paradox in new product innovation". Journal of Marketing, Vol. 69, No. 4, pp.61-83.

Cai, S., Jun, M. and Yang, Z. (2010), "Implementing supply chain information integration in China: The role of institutional forces and trust". Journal of Operations Management, Vol. 28, No. 3, pp.257-268.

Cappelli, P., Singh, H., Singh, J. and Useem, M. (2010), "The India way: Lessons for the U.S". Academy of Management Perspectives, Vol. 24, No. 2, pp.6-24.

Carey, S., Lawson, B. and Krause, D. R. (2011), "Social capital configuration, legal bonds and performance in buyer-supplier relationships". Journal of Operations Management, Vol. 29, No. 4, pp.277-288.

Chandy, R. K. and Tellis, G. J. (1998), "Organizing for radical product innovation: The overlooked role of willingness to cannibalize". Journal of Marketing Research, Vol. 34, No. 4, pp.474-487.

Chokar, J. S., Brodbeck, F. C. and House, R. J. (eds.) (2007), Culture and leadership across the world: The GLOBE book of in-depth studies of 25 societies, Lawrence Erlbaum Associates Mahwah, New Jersey.

Fan, D., Li, Y., and Chen, L. (2017), "Configuring innovative societies: The crossvergent role of cultural and institutional varieties". Technovation, Vol. 66/67, pp.43-56.

Fan, P. (2011), "Innovation capacity and economic development: China and India". Economic Change and Restructuring, Vol. 44, No. 1/2, pp.49-73.

Fornell, C. and Larcker, D. F. (1981), "Evaluating structural equation models with unobservable variables and measurement errors". Journal of Marketing Research, Vol. 18, No. 1, pp.39-50. 
Gilsing, V.A. and Duysters, G.M. (2008), "Understanding novelty creation in exploration networks - Structural and relational embeddedness jointly considered". Technovation, Vol. 28, pp.693-708.

Greene, W.H. (2012), Econometric analysis ( ${ }^{\text {th }}$ Ed.), Pearson Education Limited, England.

Guo, D., Guo, Y. and Jiang, K. (2018), "Governance and effects of public R\&D subsidies: Evidence from China". Technovation, Vol.74/75, pp.18-31.

Guo, H., Xu, E. and Jacobs, M. (2014), "Managerial political ties and firm performance during institutional transitions: An analysis of mediating mechanisms". Journal of Business Research, Vol. 67, No. 2, pp.116-127.

Hemmert, M., Kim, D., Kim, J. and Cho, B. (2016), "Building the supplier's trust: Role of instutional forces and buyer firm performance". International Journal of Production Economics, Vol.180, pp.25-37.

Hong, J., Feng, B., Wu, Y. and Wang L. (2016), "Do government grants promote innovation efficiency in China's high-tech industries?" Technovation, Vol.57/58, pp.4-13.

House, R. J., Hanges, P. J., Javidan, M., Dorfman, P. W. and Gupta, V. (eds.) (2004), Culture, leadership, and organization: The GLOBE study of 62 societies, Sage Publications, Thousand Oaks, California.

Hu, L. and Bentler, P. M. (1999), "Cutoff criteria for fit indices in covariance structure analysis: Conventional criteria versus new alternatives". Structural Equation Modeling, Vol. 6, No. 1, pp.1-55.

Jackson, M.O. (2011), "An overview of social networks and economic applications", In: J. Benhabib, A. Bisin and M.O. Jackson, (eds.), Handbook of social economics. Elsevier, pp.511-585. 
Kaasa, A. (2009), "Effects of different dimensions of social capital on innovative activity: Evidence from Europe at the regional level". Technovation, Vol.29, pp.218-233.

Kemper, J., Schilke, O. and Brettel, M. (2013), "Social capital as a microlevel origin of organizational capabilities". Journal of Product Innovation Management, Vol. 30, No. 3, pp.589-603.

Kozhikode, R. K. and Li, J. (2012), "Political pluralism, public policies, and organizational choices: Banking branch expansion in India, 1948-2003". Academy of Management Journal, Vol. 55, No. 2, pp.339-359.

Lawson, B., Tyler, B. B. and Cousins, P. D. (2008), "Antecedents and consequences of social capital on buyer performance improvement". Journal of Operations Management, Vol. 26, No. 3, pp.446-460.

Li, H. and Atuahene-Gima, K. (2001), "Product innovation strategy and the performance of new technology ventures in China". Academy of Management Journal, Vol. 44, No. 6, pp.1123-1134.

Li, H. and Zhang, Y. (2007), "The role of managers' political networking and functional experience in new venture performance: Evidence from China's transition economy". Strategic Management Journal, Vol. 28, No. 8, pp.791-804.

Li, J., Poppo, L. and Zhou, K. (2008), "Do managerial ties in China always produce value? Competition, uncertainty, and domestic vs. foreign firms". Strategic Management Journal, Vol. 29, No. 4, pp.383-400.

Li, J. and Zhou, K. (2010), "How foreign firms achieve competitive advantage in the Chinese emerging economy: Managerial ties and market orientation". Journal of Business Research, Vol. 63, No. 8, pp.856-862. 
Luk, C., Yau, O., Tse, A., Chow, R. and Lee, J. (2008), "The effects of social capital and organizational innovativeness in different institutional contexts". Journal of International Business Studies, Vol. 39, No. 4, pp.589-612.

Nahapiet, J. and Ghoshal, S. (1998), "Social capital, intellectual capital, and the organizational advantage". Academy of Management Review, Vol. 23, No. 2, pp.242-266.

Parayil, G. and D'costa, A. P. (eds.) (2009), The new Asian innovation dynamics: China and India in perspective, Palarave Macmillan, England.

Park, S. H. and Luo, Y. (2001), "Guanxi and organizational dynamics: Organizational networking in Chinese firms". Strategic Management Journal, Vol. 22, No. 5, pp.455-477.

Peng, M. and Luo, Y. (2000), "Managerial ties and firm performance in a transition economy: The nature of a micro-macro link". Academy of Management Journal, Vol. 43, No. 3, pp.486-501.

Petruzzelli, A.M. (2011), "The impact of technological relatedness, prior ties, and geographical distance on university-industry collaborations: A joint-patent analysis". Technovation, Vol.31, pp.309-319.

Podsakoff, P. M., Mackenzie, S. B., Lee, J. Y. and Podsakoff, N. P. (2003), "Common method biases in behavioral research: A critical review of the literature and recommended remedies". Journal of Applied Psychology, Vol. 88, No. 5, pp.879-903.

Power, D., Schoenherr, T. and Samson, D. (2010), "The cultural characteristic of individualism/collectivism: A comparative study of implications for investment in operations between emerging Asian and industrialized Western countries". Journal of Operations Management, Vol. 28, No. 3, pp.206-222. 
Preacher, K. and Hayes, A. (2008), "Asymptotic and resampling strategies for assessing and comparing indirect effects in multiple mediator models". Behavior Research Methods, Vol. 40, No.3, pp.879-891.

Roden, S. and Lawson, B. (2014), "Devloping social captial in buyer-supplier relationships: The contingent effect of relationship-specific adaptations". International Journal of Production Economics, Vol. 151, pp.89-99.

Rungtusanatham, M., Ng, C. H., Zhao, X. and Lee, T. S. (2008), "Pooling data across transparently different groups of key informants: Measurement equivalence and survey research". Decision Sciences, Vol. 39, No. 1, pp.115-145.

Sheng, S., Zhou, K. and Li, J. (2011), "The effects of business and political ties on firm performance: Evidence from China". Journal of Marketing, Vol. 75, No. 1, pp.1-15.

Shu, C., Page, A. L., Gao, S. and Jiang, X. (2012), "Managerial ties and firm innovation: Is knowledge creation a missing link?" Journal of Product Innovation Management, Vol. 29, No. 1, pp.125-143.

Shu, C., Wang, Q., Gao, S. and Liu, C. (2015), "Firm patenting, innovations, and government institutional support as a double-edged sword". Journal of Product Innovation Management, Vol. 32, No. 2, pp.290-305.

Tsai, W. and Ghoshal, S. (1998), "Social capital and value creation: The role of intrafirm networks". Academy of Management Journal, Vol. 41, No. 4, pp.464476.

Villena, V. H., Revilla, E. and Choi, T. Y. (2011), "The dark side of buyer-supplier relationships: A social capital perspective". Journal of Operations Management, Vol. 29, No. 6, pp.561-576. 
Wang, D., Sutherland, D., Ning, L., Wang, Y. and Pan, X. (2017), "Exploring the influence of political connections and managerial overconfidence on R\&D intensity in China's large-scale private sector firms". Technovation, Vol.69, pp. $40-53$.

Wang, L., Yeung, J. H. Y. and Zhang, M. (2011), "The impact of trust and contract on innovation performance: The moderating role of environmental uncertainty". International Journal of Production Economics, Vol. 134, No. 1, pp.114-122.

Wang, Z., Zhang, M., Sun, H. and Zhu, G. (2016), "Effects of standardization and innovation on mass customization: An empirical investigation". Technovation, Vol.48/49, pp.79-86.

World Economic Forum (2014), "The global competitiveness report 2014-2015". World Economic Forum. available at:http://www.weforum.org/reports/globalcompetitiveness-report-2014-2015 (accessed 12 September 2015)

$\mathrm{Wu}$, J. (2011), "Asymmetric roles of business ties and political ties in product innovation". Journal of Business Research, Vol. 64, No. 11, pp.1151-1156.

Yeung, J. H. Y., Selen, W., Zhang, M. and Huo, B. (2009), "The effects of trust and coercive power on supplier integration". International Journal of Production Economics, Vol. 120, No. 1, pp.66-78.

Yi, J., Hong, J., Hsu, W.C., and Wang, C. (2018), "The role of state ownership and institutions in the innovation performance of emerging market enterprises: Evidence from China". Technovation, Vol.62/63, pp.4-13.

Zhang, M., Zhao, X., Voss, C. and Zhu, G. (2016), "Innovating through services, cocreation and supplier integration: Cases from China". International Journal of Production Economics, Vol.171, pp.289-300. 
Zhou, K. and Poppo, L. (2010), "Exchange hazards, relational reliability, and contracts in China: The contingent role of legal enforceability". Journal of International Business Studies, Vol. 41, No. 5, pp.861-881. 
Appendix I. Measurement items

\begin{tabular}{|c|c|c|}
\hline & China & India \\
\hline $\begin{array}{l}\text { Political Ties (Please best describe the extent to which the senior managers at } \\
\text { your company have utilized personal ties, networks and connections during the } \\
\text { past three years with the following) }\end{array}$ & $\begin{array}{l}\mathrm{AVE}=0.77, \mathrm{CR}=0.91 \\
\mathrm{Alpha}=0.85\end{array}$ & $\begin{array}{l}\text { AVE }=0.72, \mathrm{CR}=0.88 \\
\quad \text { Alpha }=0.81\end{array}$ \\
\hline PT1: political leaders in various levels of the government & 0.881 & 0.889 \\
\hline PT2: officials in industrial bureaus & 0.861 & 0.844 \\
\hline $\begin{array}{l}\text { PT3: officials in regulatory and supporting organizations such as tax bureaus, state } \\
\text { banks, commercial administration bureaus, and the like }\end{array}$ & 0.889 & 0.808 \\
\hline $\begin{array}{l}\text { Business Ties (Please best describe the extent to which the senior managers at } \\
\text { your company have built relationships with senior managers at the following) }\end{array}$ & $\begin{array}{c}\text { AVE }=0.59, \text { CR }=0.81 \\
\text { Alpha }=0.66\end{array}$ & $\begin{array}{l}\text { AVE }=0.73, \text { CR }=0.89, \\
\quad \text { Alpha }=0.81\end{array}$ \\
\hline BT1: customers & 0.666 & 0.864 \\
\hline BT2: suppliers & 0.854 & 0.847 \\
\hline BT3: competitors & 0.770 & 0.846 \\
\hline $\begin{array}{l}\text { Cognitive Capital (Please indicate your degree of agreement with the following } \\
\text { statements) }\end{array}$ & $\begin{array}{c}\text { AVE }=0.56, C R=0.84 \\
\text { Alpha }=0.74\end{array}$ & $\begin{array}{l}\text { AVE }=0.64, \text { CR }=0.88, \\
\text { Alpha }=0.82\end{array}$ \\
\hline $\begin{array}{l}\text { CC1: The company and its major external partners have a common understanding } \\
\text { about what activities are best for our relationships }\end{array}$ & 0.762 & 0.840 \\
\hline $\begin{array}{l}\text { CC2: The company and its major external partners have shared objectives and } \\
\text { visions }\end{array}$ & 0.714 & 0.763 \\
\hline $\begin{array}{l}\text { CC3: The company and its major external partners have a common understanding } \\
\text { about the same concepts (e.g. good, fast, cost, and quality) }\end{array}$ & 0.769 & 0.794 \\
\hline $\begin{array}{l}\text { CC4: The company and its major external partners have common values and } \\
\text { cultures }\end{array}$ & 0.749 & 0.800 \\
\hline $\begin{array}{l}\text { Institutional Support (Please indicate the extent to which the government and its } \\
\text { agencies have done the following in the past three years) }\end{array}$ & $\begin{array}{l}\mathrm{AVE}=0.70, \mathrm{CR}=0.90 \\
\mathrm{Alpha}=0.86\end{array}$ & $\begin{array}{l}\text { AVE }=0.82, \mathrm{CR}=0.95 \\
\quad \text { Alpha }=0.92\end{array}$ \\
\hline $\begin{array}{l}\text { IS1: implemented policies and programs that have been beneficial to your } \\
\text { company's operations }\end{array}$ & 0.822 & 0.871 \\
\hline
\end{tabular}




\begin{tabular}{|l|c|c|}
\hline $\begin{array}{l}\text { IS2: provided needed technology information and technical support to your } \\
\text { company }\end{array}$ & 0.875 & 0.928 \\
\hline IS3: played a significant role in providing financial support for your company & 0.865 & 0.894 \\
\hline $\begin{array}{l}\text { IS4: helped your company to obtain licenses for imports of technology, } \\
\text { manufacturing and other equipment }\end{array}$ & 0.772 & 0.918 \\
\hline $\begin{array}{l}\text { Product Innovation Performance (Please compare the product innovation } \\
\text { performance of the following aspects at your company in the past three years to } \\
\text { those of your major competitors) }\end{array}$ & AVE=0.72, CR=0.91, \\
\hline PIP1: Percentage of total sales stemming from new products 0.87 & AVE=0.67, CR=0.89, \\
PIP2: Number of new products & 0.766 & 0.84 \\
\hline PIP3: Speed of introducing new products & 0.861 & 0.832 \\
\hline PIP4: Frequency of new product introductions & 0.879 & 0.821 \\
\hline Note: AVE: Average Variance Extracted; CR: Composite Reliability; Alpha: Cronbach's Alpha; The t values for the factor loadings are all greater than 2.0 and the factor loadings are standardized.
\end{tabular}


Appendix II. Multicollinearity and endogeneity test

This study conducts three multiple regression analyses with variance inflation factor (VIF) test in both Chinese and Indian samples. Specifically, product innovation performance is regressed on institutional support, cognitive capital, company size, $\mathrm{R} \& \mathrm{D}$ investment, and training investment; institutional support is regressed on business ties and political ties; and cognitive capital is regressed on business ties. The results show that the VIF coefficients range from 1.00 to 1.99 , which indicates that multicollinearity is not a serious issue in this study. This study also performs the Durbin-Wu-Hausman test for endogeneity in both Chinese and Indian samples. Specifically, cognitive capital is regressed on business ties, institutional support, company size, R\&D investment, and training investment to get the residual (r_cc); and then product innovation performance is regressed on institutional support, cognitive capital, company size, R\&D investment, training investment, and r_cc. Similarly, institutional support is regressed on business ties, political ties, cognitive capital, company size, $R \& D$ investment, and training investment to get the residual ( $r$ is); and then product innovation performance is regressed on institutional support, cognitive capital, company size, R\&D investment, training investment, and $r$ is. The results show that none of the coefficients of the residuals ( $r$ cc and $r \_i s$ ) is significantly different from 0 . Therefore, endogeneity is not a serious concern in this study. 